\title{
Re-evaluation of the Mungbean [Vigna radiata (L.) Wilczek] Genotypes for Resistance to Mungbean Yellow Mosaic Virus (MYMV) under Screen-House Conditions
}

\author{
Sugandh Suman*, V.K. Sharma, Harsh Kumar and V.K. Shahi
}

Department of Agricultural Biotechnology \& Molecular Biology, Dr. Rajendra Prasad Central Agricultural University, Pusa (Samastipur), Bihar 848 125, India

*Corresponding author

\begin{abstract}
A B S T R A C T
Keywords

Mungbean, Bemesia tabaci, MYMV,

Screening, Forced feeding method, Resistance

Article Info

Accepted:

30 March 2018

Available Online:

10 April 2018

Mungbean [Vigna radiata (L.) Wilczek] is one of the most important grain legumes grown particularly in Asia. The production of mungbean is severely hampered by mungbean yellow mosaic virus (MYMV) caused by begomoviruses transmitted by whitefly, Bemesia tabaci. The absence of resistant/tolerant sources against MYMV disease leads to tremendous crop yield losses. To identify the sources of resistance in mungbean against MYMV, 35 genotypes were screened under natural conditions and categorized into different reaction groups using rating scale. In the present study, the screened genotypes were re-evaluated under screen-house conditions in order to confirm the sources of resistance against MYMV disease incidence. Out of them, 2 were categorized as resistant (R), 6 moderately resistant (MR), 12 moderately susceptible, 14 susceptible (S) and 1 as highly susceptible (HS). The resistant and highly susceptible genotypes could be used as parents for the development of mapping population in order to validate the molecular markers to facilitate marker-assisted selection for the development of MYMV resistant breeding lines.
\end{abstract}

\section{Introduction}

Pulses are the major sources of protein in the vegetarian diet in our country. Besides being a rich sources of protein, they maintain soil fertility through biological nitrogen fixation and thus play a vital role in furthering sustainable agriculture. Among the pulses, mungbean [Vigna radiata $(\mathrm{L}$.) R. Wilczek] is one of the most important grain legumes grown particularly in Asia. It belongs to the subgenus Ceratotropis in the genus Vigna and is a self-pollinating diploid grain legume
$(2 n=22)$ with a genome size of $579 \mathrm{Mb}$ (Arumuganathan and Earle, 1991). Due to its protein rich edible seeds, its ability to fix nitrogen, drought tolerance, and early maturity, it is widely planted in various cropping systems (Tangphatsornruang et al., 2009). It is a good source of dietary protein with high contents of folate and iron compared with many other legumes crops (Keatinge et al., 2011). Other properties like easy digestibility and low proportion of flatulence factors also adds to its value among the pulse crops. The seeds and sprouts of mungbean act 
as therapeutic agents as they possess antioxidants and have antimicrobial, antiinflammatory, antidiabetic, antihypertensive and anti-cancerous effects (Tang et al., 2014).

Despite its economic importance, the average yield of this crop is low not only in India but also in the entire tropical and subtropical Asia mainly due to its susceptibility to many diseases such as mungbean yellow mosaic virus (MYMV), powdery mildew, Cercospora leaf spot (CLS), bacterial leaf spot (BLS) and leaf crinkle virus (LCV). Among the various diseases of mungbean, MYMV causes significant yield losses and under severe conditions, the yield penalty may reach upto 80 to 100 per cent (Naimuddin, 2001). It is a vital, serious, destructive, open spread and causal component of tremendous yield losses. It is caused by begomoviruses with bipartite genomes transmitted through whitefly, Bemesia tabaci (Nariani, 1960). Begomoviruses are the largest and the most important genus within the family Geminiviridae. They are plant-infecting single-stranded DNA viruses having characteristic geminate incomplete icosahedral particles. Geminiviruses often occur in disease complexes, and infect individual plant with multiple viruses. The genomes of geminiviruses can undergo high levels of mutation, recombination and reassortment to increase viral diversity (Duffy et al., 2008; Harkins et al., 2009; Martin et al., 2011; Lima et al., 2012). Due to the large populations of whiteflies, and their ability to develop pesticide resistance, vector seclusion is not anideal way of fighting the spread and damage induced by MYMV. Also, the management of MYMV disease through spray of chemicals and pesticides is not always effective because they can reduce the disease incidence to some extent but complete control is difficult. Further, the recurrent spaying of these chemicals leads to health hazards and creates adverse impact on surrounding environment (Nariani, 1960). Hence, in order to realize a sustainable agriculture and to get high quality products in terms of safe human health, the use of resistant varieties through conventional breeding appears to be a principal tool to reduce damages caused by pathogens. It would be an economic, durable and feasible approach in alleviation of disease severity as it requires no chemical input and/or plant seclusion and may be stable and long-lasting.

The screening of mungbean germplasm against MYMV disease under diverse environmental conditions is the first step in the identification of resistant donors for evolving mungbean varieties with MYMV resistance and yield. But this approach is time consuming and requires evaluation at 'hot spot' area (Selvi et al., 2006). In fact, spontaneous field-exposure infection has been shown to be largely inefficient, as many plants escape infection, even under heavy inoculation pressure (Vidaysky et al., 1998). To identify plant materials having high level of resistance, screening of genotypes using force feeding methods (Firdaus et al., 2012; Taggar et al., 2013; Sulistyo and Inayati, 2016)and agroinoculation methods (Al Abdallat et al., 2010; Karthikeyan et al., 2011; B Sai et al., 2017) has been exploited in several crops including mungbean. Therefore, it is essential to screen genotypes through forced feeding methods, which can ensure $100 \%$ infection rate, and a standardized inoculum pressure. In the present study, 35 genotypes of mungbean screened under natural conditions (Suman et al., 2015) were re-evaluated under screenhouse conditions in order to identify the resistant sources to be used further in breeding programs.

\section{Materials and Methods}

Artificial screening is most acceptable technique to identifying resistance and susceptible individual or lines (Pico et al., 1998). The experiment was conducted in two parts: field experiment and screen-house 
experiment. Thirty five genotypes were used out of which 27 were procured from IIPR, Kanpur and 8 from TCA, Dholi (Table 1).

\section{Field experiment}

The test materials were sown in randomized block design (RBD) with three replications during summer. Each test entry was planted in two consecutive rows of 3 meter long with 30 $\mathrm{cm}$ row to row distance. One row of the most susceptible check (LGG 450) was planted after every test entry. Two rows of the most susceptible check were also planted all around the experiment to create more disease.

General cultural practices were followed in order to maintain the experiment and no insecticide was sprayed in order to support the population of whitefly for the natural spread of the disease. After germination, the crop was regularly monitored for the presence of whitefly and development of MYMV disease. The genotypes were screened for their resistance to MYMV incidence and evaluated on the basis of score and per cent disease incidence. The genotypes were scored for MYMV disease and grouped into five different categories from resistant to highly susceptible based on 1 to 9 rating scales (Fig. 2 and Table 2) at flowering and pod formation stages following the procedure as used earlier by Singh et al., (1992).

\section{Screen-house experiment}

Seeds of all the genotypes were sown in pots $(24 \mathrm{X} 21 \mathrm{~cm})$ in completely randomized design (CRD) with three replications. During the period of experiment, the plants were irrigated weekly. The pots were placed in polyhouse and separated by net of mesh size $0.75 \times 0.27$ $\mathrm{mm}$ with the intention of preventing whiteflies moved to other plant and forced to breed in that plants (Fig.1). White flies were collected from the plants and confined in a susceptible plant showing typical MYMV symptoms for
$24 \mathrm{hrs}$ using a small, transparent glass trapper with a spring cap. The same trapper with the trapped flies was then used to inoculate (Polston and Capobianco, 2013) an apparently healthy plant and the viruliferous insects were allowed to feed on the leaf for $24 \mathrm{~h}$. After acquisition feeding, the flies were used for 3-5 transfers for inoculation feeding, thereby allowing the viruliferous flies to transmit MYMV into the plant. Spread of MYMV was recorded at weekly intervals till maximum infection was achieved. The number of genotypes infected per week was calculated. The genotypes were scored on the basis of the degree of incidence of MYMV disease by using 1-9 rating scale for their classification into different infection categories.

\section{Results and Discussion}

\section{Field experiment}

Yellow mosaic disease appeared on the susceptible check lines about 25-30 days after planting under natural conditions. Small yellow specks of mild intensity were observed on young leaves. Alternate yellow and green patches with irregular margins developed in the first fully formed trifoliate leaf next to the apex after one week. The intensity of disease increased with passage of time. During summer, resistant response against MYMV was observed in the genotypes IPM 02-14 and PDM 139, whereas moderately resistant response was observed in the genotypes Pant Mung 4, Pusa 9531, HUM 1, HUM 12, HUM 16, Meha, DMS 03-17-2, RMG 62 and TMB 37. The genotypes Pant Mung 5, IPM 02-03, PDM 54, SML 134, SML 668, PS 16, MH 961, Pusa Vishal, Kopergaon, OUM 11-5, Pusa 032 and Pant Mung 2 displayed moderately susceptible response, while the genotypes AKM 8803, AKM 9910, TARM 2, Pusa 105, T 44, GM 4, LGG 407, Co4, IPM 99-1-6, Pusa 031 and DM 05-74-11 exhibited susceptible response against MYMV. 
Table.1 List of mungbean genotypes used in the present study

\begin{tabular}{|c|c|c|c|}
\hline Sl. No. & Name of the genotype & Source & Developing center \\
\hline 1 & Pant Mung 4 & IIPR, Kanpur & Pantnagar \\
\hline 2 & Pant Mung 5 & IIPR, Kanpur & Pantnagar \\
\hline 3 & Pusa 9531 & IIPR, Kanpur & IARI, New Delhi \\
\hline 4 & IPM 02-03 & IIPR, Kanpur & IIPR, Kanpur \\
\hline 5 & IPM 02-14 & IIPR, Kanpur & IIPR, Kanpur \\
\hline 6 & PDM 54 & IIPR, Kanpur & IIPR, Kanpur \\
\hline 7 & PDM 139 & IIPR, Kanpur & IIPR, Kanpur \\
\hline 8 & HUM 1 & IIPR, Kanpur & BHU, Varanasi \\
\hline 9 & HUM 12 & IIPR, Kanpur & BHU, Varanasi \\
\hline 10 & HUM 16 & IIPR, Kanpur & BHU, Varanasi \\
\hline 11 & AKM 8803 & IIPR, Kanpur & PKV, Akola \\
\hline 12 & AKM 9910 & IIPR, Kanpur & PDKV, Akola \\
\hline 13 & SML 668 & IIPR, Kanpur & PAU, Ludhiana \\
\hline 14 & SML 134 & IIPR, Kanpur & PAU, Ludhiana \\
\hline 15 & PS 16 & IIPR, Kanpur & IARI, New Delhi \\
\hline 16 & TARM 2 & IIPR, Kanpur & BARC, Akola \\
\hline 17 & MH 96-1 & IIPR, Kanpur & HAU, Hisar \\
\hline 18 & Meha & IIPR, Kanpur & IIPR, Kanpur \\
\hline 19 & Pusa 105 & IIPR, Kanpur & IARI, New Delhi \\
\hline 20 & T 44 & IIPR, Kanpur & TNAU, Tamilnadu \\
\hline 21 & GM 4 & IIPR, Kanpur & S.K. Nagar, Gujarat \\
\hline 22 & LGG 407 & IIPR, Kanpur & APAU, Lam \\
\hline 23 & Pusa Vishal & IIPR, Kanpur & IARI, New Delhi \\
\hline 24 & Co 4 & IIPR, Kanpur & TNAU, Tamilnadu \\
\hline 25 & Kopergaon & IIPR, Kanpur & Local landraces \\
\hline 26 & OUM 11-5 & IIPR, Kanpur & OUAT, Berhampur \\
\hline 27 & RMG 62 & IIPR, Kanpur & Durgapura \\
\hline 28 & DMS 03-17-2 & TCA, Dholi & TCA, Dholi \\
\hline 29 & TMB 37 & TCA, Dholi & BARC, Mumbai \\
\hline 30 & Pant Mung 2 & TCA, Dholi & Pantnagar \\
\hline 31 & IPM-99-1-6 & TCA, Dholi & IIPR, Kanpur \\
\hline 32 & Pusa 032 & TCA, Dholi & IARI, New Delhi \\
\hline 33 & Pusa 031 & TCA, Dholi & IARI, New Delhi \\
\hline 34 & LGG 450 & TCA, Dholi & APAU, Lam \\
\hline 35 & DM 05-74-11 & TCA, Dholi & TCA, Dholi \\
\hline
\end{tabular}


Table.2 Rating scale for MYMV disease incidence used in the present study

\begin{tabular}{|c|c|c|}
\hline Rating & Percentage foliage affected & Infection category \\
\hline 1 & $\begin{array}{l}\text { No visible symptoms or minute yellow specks covering } 0.1-5 \% \text { leaf } \\
\text { area }\end{array}$ & Resistant (R) \\
\hline 3 & Mottling of leaves covering 5.1-15\% leaf area & Moderately $\mathrm{r}$ \\
\hline 5 & Yellow mottling and discoloration of $15.1-30 \%$ leaf area & Moderately susceptible (MS) \\
\hline 7 & $\begin{array}{l}\text { Pronounced yellow mottling and discoloration of leaves, pods } \\
\text { reducing in leaf size, stunting of plants, } 30.1-75 \% \text { foliage affected }\end{array}$ & Susceptible (S) \\
\hline 9 & $\begin{array}{l}\text { Severe yellow mottling and discoloration of leaves, stunting of plants, } \\
\text { failure of flowering and fruit setting } 75.1-100 \% \text { foliar affected }\end{array}$ & Highly susceptible (HS) \\
\hline
\end{tabular}

Table.3 Distribution of mungbean genotypes in various infection categories for MYMV disease incidence under screen-house conditions

\begin{tabular}{|c|c|c|c|}
\hline Disease scale & Rating & No. of genotypes & Genotypes involved \\
\hline Resistant (R) & 1 & 2 & IPM 02-14, PDM139 \\
\hline $\begin{array}{l}\text { Moderately resistant } \\
\text { (MR) }\end{array}$ & 3 & 6 & $\begin{array}{l}\text { DMS 03-17-2, HUM 1, HUM 16, Pant Mung 4, } \\
\text { RMG 62, TMB } 37\end{array}$ \\
\hline $\begin{array}{l}\text { Moderately susceptible } \\
\text { (MS) }\end{array}$ & 5 & 12 & $\begin{array}{l}\text { Pant Mung 5, Pusa 9531, IPM 02-03, PDM 54, } \\
\text { HUM 12, SML 668, SML 134, Meha, Pusa } \\
\text { Vishal, MH 96-1, Pant Mung 2, Pusa } 032\end{array}$ \\
\hline Susceptible (S) & 7 & 14 & $\begin{array}{l}\text { AKM 8803, AKM 9910, PS 16, TARM 2, Pusa } \\
\text { 105, T 44, LGG 407, Kopergaon, Co 4, GM } 4 \text {, } \\
\text { OUM 11-5, IPM 99-1-6, Pusa 031, DM 05-74- } \\
11\end{array}$ \\
\hline Highly susceptible (HS) & 9 & 1 & LGG 450 \\
\hline
\end{tabular}

Fig.1 Screening of mungbean genotypes for resistance against MYMV under screen-house conditions

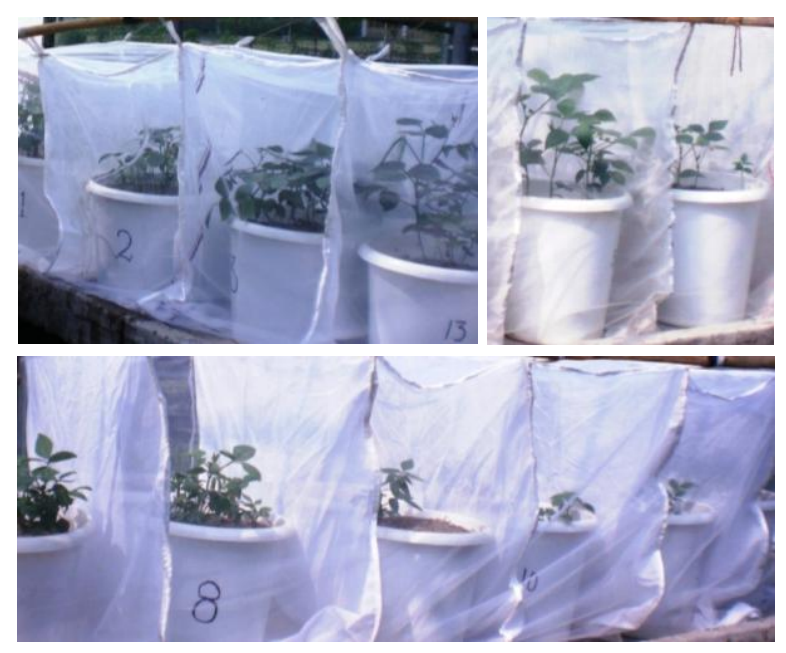


Fig.2 Symptoms of different reaction categories against MYMV disease based on rating scale
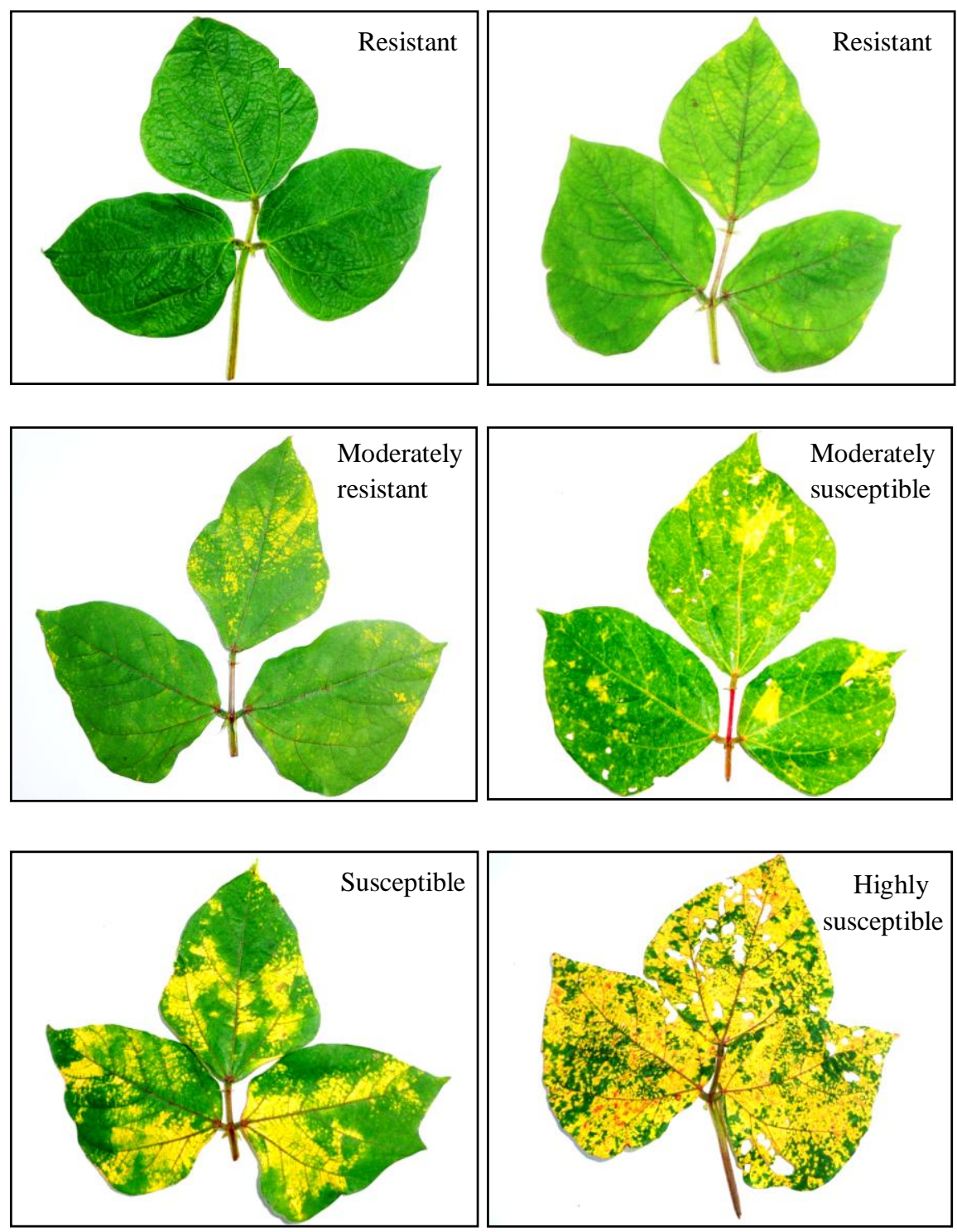

The genotype LGG 450 showed highly susceptible reaction against MYMV disease incidence. The degree of disease incidence against MYMV ranged from 2.77 per cent in the resistant genotype IPM 02-14 to 83.33 per cent in the highly susceptible genotype LGG 450. The disease incidence for moderately resistant, moderately susceptible and susceptible response varied from 10 per cent in Pant Mung 4 to 15 per cent in HUM 12, 19.98 per cent in PDM 54 to 29.45 per cent in OUM 11-5 and 32.22 per cent in GM 4 to 41.67 per

cent in LGG 407, respectively (Suman et al., 2016).

\section{Screen-house experiment}

Germination was completed within a week. The first appearance of MYMV disease was recorded in several genotypes two weeks after planting. Mild to severe yellow specks were observed on young leaves. Within next two weeks, these specks increased, coalesced and turned into yellow and green patches. The 
severity of disease increased with the passage of time. Thirty five days after sowing, all the infected plants turned completely yellow and pods developed mottling symptoms and contained few shriveled seeds. All the genotypes were categorized using disease rating (1-9) scale into resistant (R), moderately resistant (MR), moderately susceptible (MS), susceptible (S) and highly susceptible (HS) infection categories. While assessing the performance of the entries in terms of the number of genotypes involved in different reaction categories it was found that two, six and twelve genotypes showed resistant, moderately resistant and moderately susceptible categories of disease reaction against MYMV, respectively. Amongst the rest of the genotypes under evaluation, fourteen genotypes were grouped under the susceptible category, while a single genotype was placed in highly susceptible group (Table 3 ).

The reaction pattern of the mungbean genotypes evaluated under screen-house conditions showed slight differences for MYMV disease incidence as compared to the genotyped screened under natural conditions. Three genotypes namely, Pusa 9531, HUM12 and Meha which were screened as moderately resistant under natural conditions were found to be moderately susceptible under screen-house conditions. Similarly, the genotypes namely, PS16, Kopergaon and OUM 11-5 which were rated as moderately susceptible under natural conditions were confirmed as susceptible under screen-house conditions using forced feeding methods. Inconsistency in results of some of the genotypes possibly may be due to the effect of location, disease pressure and virus strain. It is established that initial period of 2-3 weeks is highly critical due to early landing of viruliferous whitefly for the development and spread of MYMV. Increasing incidence and epiphytotic conditions of MYMV depend upon a combination of factors such as high population of viruliferous whitefly, buildup of inoculum potential in some hosts and wide range of favorable environmental conditions (Shad et al., 2006). However, it has also been reported that certain morphological leaf characteristics and foliar pubescence may affect insect feeding preference on plant genotypes (Taggar and Gill, 2012; Soundararajan et al., 2013; Tamang et al., 2017).

In the present investigation, forced feeding method served as an efficient tool for reevaluation of the mungbean genotypes screened under natural conditions. The resistant and the highly susceptible genotypes showed similar responses under both natural and screen-house conditions. However, only some of the genotypes in the intermediate categories showed slight variable responses for MYMV disease incidence under screen-house conditions. Forced feeding method has also been used earlier by several workers (Basak $e t$ al., 2004; Kundagrami et al., 2009; Maiti et al., 2011) in order to confirm the nature of reaction of parents and segregating mapping populations against MYMV disease. The screening for MYMV disease incidence resulted in the identification of two resistant genotypes namely IPM 02- 14 and PDM 139 and a highly susceptible genotype, LGG 450 . These resistant and highly susceptible genotypes could be utilized as parents for the development of mapping population to validate the molecular markers which can facilitate marker-assisted selection (MAS) for the development of MYMV resistant breeding lines.

\section{Acknowledgements}

The first author is grateful to the DST, New Delhi for funding the research program through Inspire Fellowship. Authors are also thankful to the Department of Agricultural Biotechnology and Molecular Biology, Dr. Rajendra Prasad Central Agricultural University, Pusa for providing laboratory facilities and other necessary support for carrying out the research.

\section{References}

Al Abdallat, A.M., Al Debei, H.S., Asmar, H., Misbeh, S., Quraan, A. and Kvarnheden, A. 2010. An efficient in vitro-inoculation 
method for tomato yellow leaf curl virus. Virology Journal. 7:84.

Arumuganathan, K. and Earle, E. 1991. Nuclear DNA content of some important plant species. Plant Molecular Biology Report. 9: 208-218.

Basak, J., Kundagramy, S., Ghose, T.K. and Pal, A. 2004. Development of yellow mosaic virus (YMV) resistance linked DNA-marker in Vigna mungo from population segregating for YMV reaction. Molecular Breeding. 14: 375-383.

Duffy, S. and Holmes, E.C. 2008. Phylogenetic evidence for rapid rates of molecular evolution in the single-stranded DNA begomovirus tomato yellow leaf curl virus. Journal of Virology. 82: 957-965.

Firdaus, S., Van Heusden, A., Hidayati, N., Supena, E.D., Visser, R.G. and Vosman, B. 2012. Resistance to Bemisia tabaci in tomato wild relatives. Euphytica. 187: 3145.

Harkins, G.W., Delport, W., Duffy, S., Wood, N., Monjane, A.L., Owor, B.E., Donaldson, Saumtally S. and Triton G. 2009. Experimental evidence indicating that mastreviruses probably did not codiverge with their hosts. Journal of Virology. 6:104.

Karthikeyan, A., Sudha, M., Pandiyan, M., Senthil, N., Shobana, V.G. and Nagarajan, P. 2011. Screening of MYMV Resistant Mungbean (Vigna radiata L. Wilczek) Progenies through agroinoculation. International Journal of Plant Pathology. 2: 115-125.

Keatinge, J.D.H., Yang, R.Y., Hughes, Jd'A., Easdown, W.J. and Holmer, R. 2011. The importance of vegetables in ensuring both food and nutritional security in attainment of the millennium development goals. Food Science. 3: 491-501.

Kundagrami, S., Basak, J., Maiti, S., Kundu, A., Das, B. and Ghose, T.K. 2009. Agronomic, genetic and molecular characterization of MYMIV-tolerant mutant lines of Vigna mungo. International Journal of Plant Breeding and Genetics. 3: 1-10.
Lima, A.T.M., Sobrinho, R.R., Gonza'lez, A.J., Rocha, C.S., Silva, S.J.C., Xavier, C.A.D., Silva, F.N., Duffy, S. and Zerbini, F.M. 2012. Synonymous site variation due to recombination explains higher variability in begomovirus populations infecting non-cultivated hosts. Journal of General Virology. 94: 418-431.

Maiti, S., Basak, J., Kundagrami, S., Kundu, A. and Pal, A. 2011. Molecular marker assisted genotyping of mungbean yellow mosaic India virus resistant germplasms of mungbean and urdbean. Molecular Biotechnology. 47: 95-104.

Martin, D.P., Willment, J.A. and Rybicki, E.P. 1999. Evaluation of maize streak virus pathogenicity in differentially resistant Zea mays genotypes. Phytopathology. 89: 695-700.

Naimuddin. 2001. Major viral diseases of pulses and their management. Technical Bulletin No. IIPR/2001/11. Indian Institute of Pulse Research, Kanpur. pp. 1-22.

Nariani, T.K. 1960. Yellow mosaic of mungbean. Indian Phytopathology. 13: 24-29.

Pico, B., Diez, M.J. and Nuez, F. 1998. Evaluation of whitefly mediated inoculation techniques to screen Lycopersicon esculentum and wild relatives for resistance to TYLCV. Euphytica. 101: 259-271.

Polston, J.E. and Capobianco, H. 2013. Transmitting plant viruses using whiteflies. Journal of Visualized Experiments. 81: 1-10.

Sai, B., C., Nagarajan, P., Raveendran, M., Rabindran, R., Kannan Bapu, J.R. and Senthil, N. 2017. Understanding the inheritance of mungbean yellow mosaic virus (MYMV) resistance in mungbean (Vigna radiata L. Wilczek). Molecular Breeding. 37: 63.

Selvi, R., Muthiah, A.R., Manivannan, N. and Manickam, A. 2006. Tagging of RAPD marker for MYMV resistance in mungbean (Vigna radiata (L.) Wilczek). 
Asian Jouranl of Plant Sciences. 5: 277280.

Singh, G., Sharma, Y.R. and Kaur, L. 1992. Method of rating mungbean yellow mosaic virus in mungbean and urdbean. Plant Disease Research. 7: 1-6.

Soundararajan, R.P., Chitra, N. and S. Geetha. 2013. Host plant resistance to insect pests of grain legumes - a review. Agricultural Reviews. 34: 176-187.

Sulistyo, A. and Inayati, A.2016. Mechanisms of antixenosis, antibiosis, and tolerance of fourteen soybean genotypes in response to whiteflies (Bemisia tabaci). Biodiversitas. 17: 447- 453.

Suman, S., Kumar, M., Sharma, V.K. and Kumar, H. 2016. Correlation of weather parameters with incidence of mungbean yellow mosaic virus (MYMV) disease in mungbean [Vigna radiata (L.) Wilczek]. International Journal of Agricultural and Statistical Sciences. Supplement 1: 109. 115.

Suman, S., Sharma, V.K., Kumar, H. and Shahi, V.K. 2015. Screening of mungbean [Vigna radiata (L.) Wilczek] genotypes for resistance to mungbean yellow mosaic virus (MYMV). Environment and Ecology. 33: 855-859.

Taggar, G.K. and Gill R.S. 2012. Preference of whitefly, Bemisia tabaci, towards black gram genotypes: Role of morphological leaf characteristics. Phytoparasitica. 40:461-474.

Taggar, G.K., Gill, R.S. and Sandhu, J.S. 2013. Evaluation of Black Gram [Vigna mungo (L.) Hepper] genotypes against whitefly, Bemisia tabaci (Gennadius) under screenhouse conditions. Acta Phytopathologica et Entomologica Hungarica. 48:53-62.

Tamang, S., Venkatarao, P. and Chakraborty, G. 2017. Varietal screening of mungbean cultivars for resistance/tolerance against insect pest under Terai Agro ecological zone of West Bengal. International Journal of Plant Protection. 10: 7-13.

Tang, D., Dong, Y., Ren, H., Li, L. and He, C. 2014. A review of phytochemistry, metabolite changes, and medicinal uses of the common food mungbean and its sprouts (Vigna radiata). Chemistry Central Journal. 8: 2-9.

Tangphatsornruang, S., Somta, P., Uthaipaisanwong, P., Chanprasert, J., Sangsrakru, D., Seehalak, W. and Srinives P. 2009. Characterization of microsatellites and gene contents from genome shotgun sequences of mungbean (Vigna radiata (L.) Wilczek). BMC Plant Biology. 9: 137.

Vidavsky, F. and Czosnek, H. 1998. Tomato breeding lines resistant and tolerant to tomato yellow leaf curl virus issued from Lycopersicon esculentum. Phytopathology. 88: 910-914.

\section{How to cite this article:}

Sugandh Suman, V.K. Sharma, Harsh Kumar and Shahi, V.K. 2018. Re-evaluation of the Mungbean [Vigna radiata (L.) Wilczek] Genotypes for Resistance to Mungbean Yellow Mosaic Virus (MYMV) under Screen-House Conditions. Int.J.Curr.Microbiol.App.Sci. 7(04): 2821-2829. doi: https://doi.org/10.20546/ijcmas.2018.704.321 